\title{
WMA investigates its future president
}

$\mathrm{T}$ he World Medical Association (WMA) has resumed investigating legal claims against its president-elect, Dr. Ketan Desai, a urologist from India. Desai has been dogged by legal charges since he was first elected WMA president in 2009. Those charges prevented him from assuming presidency in 2010 , but in 2013, after WMA was assured by the Indian Medical Association (IMA) that all charges against him had been withdrawn, Desai was slotted in for the 2016 WMA presidency.

Now recent reports from the Reuters news agency suggest Desai may remain in legal jeopardy with two upcoming cases concerning bribery allegations in Indian courts. According to Reuters, Desai denies any wrongdoing.

WMA spokesman Nigel Duncan says they will contact the IMA about the Reuters reports but plans are in place to allow Desai to become president in 2016. The WMA represents 111 national medical associations, including the Canadian Medical Association (CMA), and is the world's leading medical ethics body.

"On a whole host of issues we rely on information from our national association members," says Duncan. "That's what we've been doing for these last five or six years [with Desai]. We're now trying to verify what the actual situation is. Although, what happens when we get the information isn't clear."

According to a Reuters' review of Indian court records and interviews with parties involved in both cases, the charges of alleged bribery and corruption have not been withdrawn and legal proceedings are ongoing. Both charges

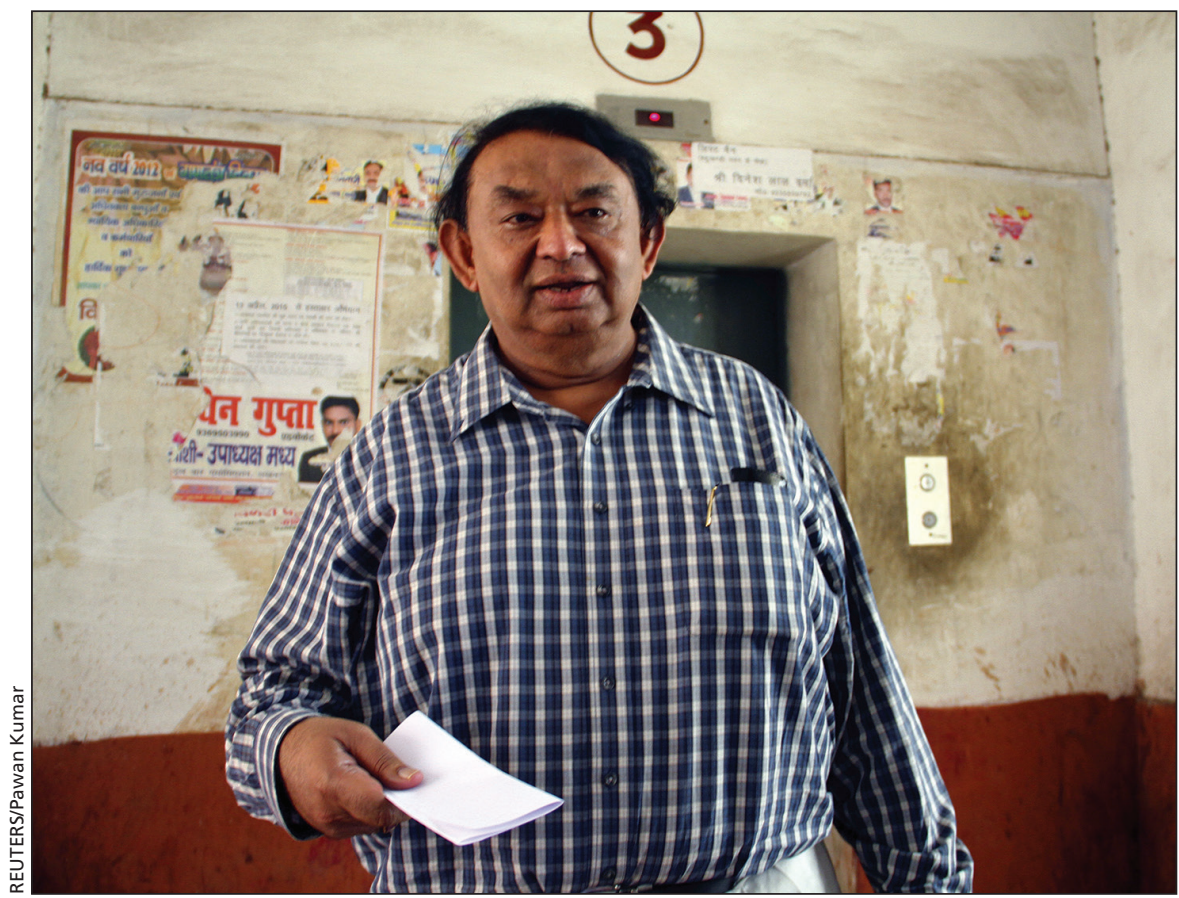

Dr. Ketan Desai, the incoming president of the World Medical Association, walks out of a Lucknow, India, courthouse following a hearing on June 27.

stem from when Desai was president of the Medical Council of India, which regulates medical schools.

Desai faces charges in a Lucknow court that he conspired to have the medical council recommend that a private medical college be allowed to enrol more students. Reuters reports that Desai also faces charges in a New Delhi court of being involved in a conspiracy to obtain a 20-million rupee bribe in return for having the medical council recommend allowing another school to take on more students. Desai's licence to practise medicine was suspended between 2010 and 2013.

The CMA's Executive Director of the Office of Ethics, Professionalism and International Affairs, Dr. Jeff
Blackmer, says he has watched Desai's status closely since 2010 .

"We've been part of the process with other associations," says Blackmer, who stressed that he would like to see Desai's legal status fully clarified well in advance of an upcoming WMA summit in Moscow.

"At this point it's very important to get some clarity. This new development raises questions. Our impression had been that the legal process had run its course. Most of our information was coming from the IMA. There is obviously a bit of a disconnect between what IMA said and what Reuters was told." — Paul Christopher Webster, Toronto

CMAJ 2015. DOI:10.1503/cmaj.109-5128 